\title{
Influence of Exercise Training on Skeletal Muscle Insulin Resistance in Aging: Spotlight on Muscle Ceramides
}

\author{
Paul T. Reidy ${ }^{1}$, Ziad S. Mahmassani ${ }^{2}$, Alec I. McKenzie ${ }^{2}$, Jonathan J. Petrocelli ${ }^{2}$, \\ Scott A. Summers ${ }^{3}$ and Micah J. Drummond ${ }^{2, *}$ (I) \\ 1 Department of Kinesiology and Health, Miami University, 420 S Oak St, Oxford, OH 45056, USA; \\ reidypt@miamioh.edu \\ 2 Departments of Physical Therapy and Athletic Training, University of Utah, 520 Wakara Way, Salt Lake City, \\ UT 84018, USA; Ziad.Mahmassani@health.utah.edu (Z.S.M.); alec.mckenzie@utah.edu (A.I.M.); \\ jonathan.petrocelli@utah.edu (J.J.P.) \\ 3 Department of Nutrition and Integrative Physiology, University of Utah, 2501850 E, Salt Lake City, \\ UT 84112, USA; scott.a.summers@health.utah.edu \\ * Correspondence: micah.drummond@hsc.utah.edu \\ Received: 3 January 2020; Accepted: 7 February 2020; Published: 22 February 2020

\begin{abstract}
Intramuscular lipid accumulation has been associated with insulin resistance (IR), aging, diabetes, dyslipidemia, and obesity. A substantial body of evidence has implicated ceramides, a sphingolipid intermediate, as potent antagonists of insulin action that drive insulin resistance. Indeed, genetic mouse studies that lower ceramides are potently insulin sensitizing. Surprisingly less is known about how physical activity (skeletal muscle contraction) regulates ceramides, especially in light that muscle contraction regulates insulin sensitivity. The purpose of this review is to critically evaluate studies (rodent and human) concerning the relationship between skeletal muscle ceramides and IR in response to increased physical activity. Our review of the literature indicates that chronic exercise reduces ceramide levels in individuals with obesity, diabetes, or hyperlipidemia. However, metabolically healthy individuals engaged in increased physical activity can improve insulin sensitivity independent of changes in skeletal muscle ceramide content. Herein we discuss these studies and provide context regarding the technical limitations (e.g., difficulty assessing the myriad ceramide species, the challenge of obtaining information on subcellular compartmentalization, and the paucity of flux measurements) and a lack of mechanistic studies that prevent a more sophisticated assessment of the ceramide pathway during increased contractile activity that lead to divergences in skeletal muscle insulin sensitivity.
\end{abstract}

Keywords: sphingolipids; fitness; obesity; insulin sensitivity; physical activity

\section{Introduction}

Obesity is a mounting health problem and the percentage of those who meet the classification is anticipated to double or triple in the next 40 years [1,2]. Obesity predisposes one to develop type 2 diabetes mellitus (T2DM), the prevalence of which is also expanding at an alarming rate [3]. Metabolic impairments associated with obesity increase the risk of developing other troubling health conditions (e.g., cardiovascular disease, peripheral vascular disease, and neuropathy), leading to enormous healthcare cost and decreased quality of life [3,4]. The hallmarks of obesity and T2DM, glucose intolerance and insulin resistance, can be observed before their respective diagnoses during a state of pre-diabetes.

Of those suffering from these metabolic derangements, older adults make the largest proportion and as of $2017 \sim 48 \%$ of older adults are considered pre-diabetic [5]. Since insufficient physical activity is one of the top 10 leading causes of mortality across the globe [6] it is no surprise that inactivity is also one of the primary causes of metabolic dysfunction $[7,8]$ and that many of the aging-related declines in health are related to low physical activity levels [9-11]. It is now well understood that older 
adults have the highest prevalence of inactivity both in the United States [12] and across the globe [6]. Physical activity is arguably the most comprehensive prevention and treatment for obesity [11] and its metabolic comorbidities $[7,8,13,14]$. Interestingly, the insulin resistance (IR) associated with aging may share a similar mechanism to that of IR that accompanies physical inactivity [15-18], further indicating the linkage between aging and physical inactivity.

The focus of this review is to examine the effects of physical activity in aging on a class of lipid intermediates, ceramides, that have been implicated in obesity and inflammation-induced skeletal muscle insulin resistance and impair insulin signaling downstream of the receptor [19].

\subsection{Skeletal Muscle Ceramides and Physical Inactivity-Induced Insulin Resistance}

Can ceramides, a dominant mechanism of diet-induced IR, also be a viable candidate by which physical activity (exercise) induces major swings in insulin sensitivity? To address this question, we evaluated the literature comprising rodent and human investigations of chronic exercise in the context of aging. We considered whether the robust changes in insulin sensitivity tied to exercise habituation correspond with the levels of skeletal muscle ceramides, as well as with the expression or activity of enzymes governing ceramide metabolism. Although, we will discuss all phenotypes, for the purpose of this review, our primary focus was on healthy phenotypes (non-obese, non-diabetic adults), across the lifespan in order to remove the confounding effects of current metabolic dysfunction and understand the extent to which the pathways related to overnutrition-induced muscle dysfunction relate to the pathways resulting from physical activity.

A hallmark of diabetes is obesity and the ectopic deposit of fat in many tissues, including skeletal muscle [20]. An overabundance of intramuscular lipids leads to an accumulation of lipid intermediates (diacylglycerol (DAG), acetylcarnitines, and ceramides) as a mass action effect, with some of these lipid intermediates worsening insulin sensitivity by inhibiting insulin signaling [21]. In addition, obesity-induced redox stress and inflammation intensify the metabolic dysfunction [22]. Clever genetic interventions in rodent models indicate with certainty that ceramides drive obesity-induced IR in pre-clinical models $[19,23]$, but their role in human insulin resistance has been controversial [24]. Additionally, aging skeletal muscle has been associated with greater skeletal muscle ceramide in some cases [25-27], but not others [28,29] and it is unclear if this is the result of aging per se or due to a progressive decline in physical activity levels over the years. The dilemma is exacerbated when examining models of physical activity, which has received far less attention, and no studies using genetic models to pinpoint mechanisms.

\subsection{Source of Substrate for Production and/or Accumulation of Ceramide in Muscle}

Ceramide production relies on the availability of fatty acids and serine, and the overabundance of these nutrient precursors drives accumulation of the sphingolipid in models of overnutrition [20,21,30]. Not all dietary fats are considered equal, as ceramides are highly dependent upon the presence of saturated fatty acids such as palmitate. Of note, exercise stimulates lipolysis to provide free fatty acids (FFAs) as energy for contracting muscles. Ceramide content in various tissues may also be regulated through tissue export and import to and from different tissue types. For example, the liver can export ceramides on very low density lipoproteins (v-LDL) for delivery to muscle [31]. Additionally, sphingoid bases can be exported from muscle into the circulation [32,33].

The diversity of ceramide species is a reflection of the activity of the six ceramide synthase (CERS) enzyme isoforms, which differ by tissue distribution and substrate specificity (for more detailed review see [34]). CERS1, 4, 5 and 6 have the highest expression in skeletal muscle thus their C-16:0 and C-18:0 ceramide products are the most abundant [34] in the tissue. Coincidentally, these species are also most commonly related to IR [35-37], specifically in human skeletal muscle [37-41].

\subsection{Intracellular Biochemical Pathways and Enzymes Controlling Ceramides}

Of the thousands of sphingolipids present in cells, ceramides are a particularly intriguing class of molecules. In addition to serving as common precursors for all other highly abundant sphingolipids, 
they have distinct bioactivities in cellular stress responses [42]. Ceramide production occurs through three pathways: de novo synthesis from fatty acids and serine; a salvage pathway that occurs through its degradation and re-formation in lysosomes; or sphingomyelin hydrolysis [42].

De novo biosynthesis of ceramide starts with the rate limiting condensation of palmitoyl-CoA with L-serine through serine palmitoyltransferase (SPT), producing the transient intermediate 3-ketosphinganine. 3-ketosphinganine is then reduced to sphinganine by 3-ketosphinganine reductase. The (dihydro)ceramide synthase (CerS 1-6) enzymes acylate sphinganine to generate dihydroceramide, which is further modified by dihydroceramide desaturase (DEGS 1-2) through the placement of a 4,5-trans-double bond. At this point ceramide can be metabolized to (1) glycosphingolipids through glucosylceramide synthase, (2) ceramide-1 phosphate with a ceramide kinase, or (3) sphingomyelin through sphingomyelin synthases.

The salvage and sphingomyelinase pathways also influence ceramide levels. Hydrolysis of the far more abundant sphingomyelin can occur in plasma membranes or intracellular organelles. The various SMases, including neutral $\mathrm{Mg}^{++}$dependent sphingomyelinase (nSMase) or acid sphingomyelinase (aSMase), transfer the choline residue of SM to DAG to generate phosphatidylcholine. The rate of ceramide degradation is also controlled by three isoforms of ceramidase: acid (aCDase), neutral (nCDase) and alkaline (alCDase). These enzymes hydrolyze the lipid to generate sphingosine and a FFA. Recent studies have found that adiponectin receptors are another class of ceramidases, degrading the lipid in response to the binding of the insulin-sensitizing adipokine [43-46]. The sphingosine produced from these ceramidase reactions can, in turn, be phosphorylated to produce sphingosine-1-phosphate (S1P), which has its own set of biological actions, often opposing those of ceramides.

Theoretically, ceramide accumulation in skeletal muscle could arise through several potential routes: (1) increased availability of substrate for ceramide biosynthesis through mass increases in circulating FFA [47]; (2) reduced palmitate oxidation and increased partitioning of palmitate [48]; (3) increased ceramide de novo synthesis via activation of toll-like receptor 4 (TLR4) [49,50] or tumor necrosis factor alpha (TNF $\alpha$ ) [51]; (4) decreased ceramide turnover [37]; (5) increased sphingomyelinase activity; (6) increased serum delivery via circulating low density lipoprotein (LDL) [52]; (7) reduced ceramide clearance; or (8) a combination of the above. These factors could be predicted to promote ceramide abundance as a result of inactivity to potentially promote muscle IR. However, most of these routes have not been investigated in the context of physical activity in humans or rodents.

\section{Aging and Ceramide}

Skeletal muscle IR is a common feature of aging $[15,53]$, but it has yet to be determined if this metabolic defect is the result of biological aging, ceramides or influenced by the lifestyle changes common in aging (Table 1). For example, two independent cross-sectional studies have demonstrated that activity levels and obesity (rather than aging) influence muscle insulin sensitivity [54,55], but ceramides were not measured. Aging skeletal muscle has been associated with greater skeletal muscle ceramide in some cases [25-27], but not others [28,29]. The reasons for these discrepancies may stem from the confounding influence of obesity in aging and differences in the methods to assay ceramides. In the cases were ceramides were more abundant in aging, the older adults were obese [25-27], but ceramides were similar [29] or even greater in the young [28] when examining leaner age groups. It is interesting to note that greater fitness levels appear to disassociate the relationship between increased age and muscle ceramide content and potentially with insulin sensitivity. In their first study, Søgaard et al. found greater content of ceramides, including the C:16 and C:18 species in the young compared to the old participants [28], but this may be due to the lean status or greater fitness level $\left(\mathrm{VO}_{2}\right.$ peak: $\left.30-40 \mathrm{~mL} \cdot \mathrm{kg}^{-1} \cdot \mathrm{min}^{-1}\right)$ in both the old and young groups compared to the cohort in their next report demonstrating a greater content with aging [25]. In that report their cohort of old and young participants was obese and had a lower fitness level $\left(\mathrm{VO}_{2}\right.$ peak: 20-30 $\mathrm{mL} \cdot \mathrm{kg}^{-1} \cdot \mathrm{min}^{-1}$ ) [25]. Future investigations need to isolate the effect of body composition, fitness level and aging on skeletal muscle ceramides. 
Table 1. Cross-sectional studies in aging humans at baseline.

\begin{tabular}{|c|c|c|c|c|c|c|c|c|c|c|c|}
\hline Reference & Subjects & Age (y) & $\begin{array}{l}\text { Aerobic } \\
\text { Fitness }\end{array}$ & Health/BMI & $\begin{array}{l}\text { Ceramide } \\
\text { Method }\end{array}$ & $\begin{array}{l}\text { Muscle } \\
\text { Ceramide }\end{array}$ & $\begin{array}{l}\text { Ceramide } \\
\text { Species }\end{array}$ & IS Method & IS & $\begin{array}{l}\text { Associations } \\
\text { with IS }\end{array}$ & Other \\
\hline \multirow[b]{2}{*}{$\begin{array}{l}\text { Rivas et al. } \\
\text { (2012) [26] }\end{array}$} & $\begin{array}{l}\text { Young } \\
(9 \mathrm{M})\end{array}$ & $22 \pm 1$ & - & Lean & \multirow[b]{2}{*}{ HPLC-MS } & - & - & - & - & \multirow[b]{2}{*}{$\begin{array}{c}\text { None } \\
\text { examined }\end{array}$} & \multirow{2}{*}{$\begin{array}{c}\text { C:16 - } \\
\text { associated with } \\
\text { leg lean mass } \\
\text { and strength }\end{array}$} \\
\hline & Old (10 M) & $74 \pm 2$ & - & OW & & $=$ Young & $\begin{array}{c}\text { > C:16, C:20 } \\
\text { and Sat vs. } \\
\text { Young }\end{array}$ & - & - & & \\
\hline \multirow{2}{*}{$\begin{array}{l}\text { Moro et al. } \\
\text { (2009) [27] }\end{array}$} & $\begin{array}{c}\text { Lean } \\
(10 \mathrm{M} / 6 \mathrm{~F})\end{array}$ & $24 \pm 1$ & - & Lean & \multirow[t]{2}{*}{ LC/ESI/MS/MS } & & & \multirow[t]{2}{*}{ HE Clamp^ } & $8.3 \pm 0.7$ & \multirow{2}{*}{$\begin{array}{l}\text { Ceramides not } \\
\text { associated } \\
\text { with age }\end{array}$} & \multirow{2}{*}{$\begin{array}{l}\text { IMTG + } \\
\text { correlated with } \\
\text { ceramides }\end{array}$} \\
\hline & $\begin{array}{c}\text { Obese } \\
(14 \mathrm{M} / 18 \mathrm{~F})\end{array}$ & $41 \pm 3$ & - & Obese & & $\begin{array}{l}\text { > vs. Lean } \\
\text { Young }\end{array}$ & $\begin{array}{c}\text { > Sat vs. Lean } \\
\text { Young }\end{array}$ & & $6.1 \pm 0.4$ & & \\
\hline \multirow{2}{*}{$\begin{array}{l}\text { Søgaard et al. } \\
\text { (2019) } \\
{[28]}\end{array}$} & $\begin{array}{l}\text { Young } \\
(11 \mathrm{M})\end{array}$ & $23 \pm 1$ & $\begin{array}{c}\mathrm{VO}_{2} \text { peak-Rel: } \\
46 \pm 1^{*}\end{array}$ & Lean & \multirow[t]{2}{*}{ TLC-HPLC } & $622 \pm 74$ & $\begin{array}{l}\text { > C:16, C:18, } \\
\text { C:22 vs. both } \\
\text { OLD }\end{array}$ & \multirow{2}{*}{ 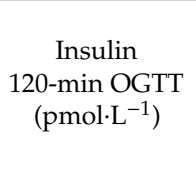 } & $87.9 \pm 14.8$ & \multirow{2}{*}{$\begin{array}{l}\text { In young: No } \\
\text { association in } \\
\text { the old }\end{array}$} & - \\
\hline & Old (18 M) & $66 \pm 1$ & $\begin{array}{c}\mathrm{VO}_{2} \text { peak-Rel: } \\
31 \pm 1^{*}\end{array}$ & Lean/OW & & $410 \pm 66$ & - & & $97.6 \pm 55.3$ & & - \\
\hline \multirow{3}{*}{$\begin{array}{l}\text { Chee et al. } \\
2016 \text { [29] }\end{array}$} & $\begin{array}{l}\text { Young Lean } \\
\quad(n=7)\end{array}$ & $21 \mathrm{y} \pm 1$ & $\begin{array}{c}\text { VO2peak-Rel: } \\
57 \pm 2 \ddagger\end{array}$ & Lean & \multirow{3}{*}{ LC/ESI/MS/MS } & - & - & \multirow{3}{*}{$\begin{array}{c}\text { HE Clamp, } \\
(\mathrm{mg} \cdot \mathrm{kg} \\
\left.\text { LBM }^{-1} \cdot \mathrm{min}^{-1}\right) \\
\& \text { skeletal } \\
\text { muscle 2-DG } \\
\text { accumulation }\end{array}$} & $65 \pm 6.0$ & \multirow{3}{*}{$\begin{array}{l}\text { Only with } \\
\text { overweight }\end{array}$} & - \\
\hline & $\begin{array}{l}\text { Old Lean } \\
(n=7)\end{array}$ & $70 \pm 1$ & $\begin{array}{c}\mathrm{VO}_{2} \text { peak-Rel: } \\
45 \pm 2 \ddagger\end{array}$ & Lean & & - & - & & $58 \pm 6$ & & - \\
\hline & $\begin{array}{c}\text { Old } \\
\text { Overweight } \\
(n=7)\end{array}$ & $69 \pm 1$ & $\begin{array}{l}\mathrm{VO}_{2} \text { peak-Rel: } \\
40 \pm 2 \ddagger\end{array}$ & OW & & - & $\begin{array}{c}\text { C:20: > Young } \\
\text { Lean }\end{array}$ & & $42 \pm 5$ & & $\begin{array}{c}\text { largely driven } \\
\text { by differences } \\
\text { in BW }\end{array}$ \\
\hline \multirow{2}{*}{$\begin{array}{l}\text { Søgaard et al. } \\
\text { (2019) [25] }\end{array}$} & $\begin{array}{c}\text { Young } \\
(5 \mathrm{M} / 9 \mathrm{~F})\end{array}$ & $32 \pm 2$ & $\begin{array}{l}\mathrm{VO}_{2} \text { max-Rel: } \\
28.3 \pm 1.2\end{array}$ & Obese & \multirow[b]{2}{*}{ LC/ESI/MS/MS } & - & - & & $2.14 \pm 0.24$ & \multirow[b]{2}{*}{ Not reported } & \multirow[t]{2}{*}{-} \\
\hline & $\begin{array}{c}\text { Old } \\
(11 \mathrm{M} / 11 \mathrm{~F})\end{array}$ & $63 \pm 1$ & $\begin{array}{l}\mathrm{VO}_{2} \text { max-Rel: } \\
25.2 \pm 1.0\end{array}$ & Obese & & $\begin{array}{c}\text { Sat, C:16, C:18, } \\
\text { C:18:1: > } \\
\text { Young Obese }\end{array}$ & $\begin{array}{c}\text { Sat, C:16, C:18, } \\
\text { C:18:1: > } \\
\text { Young Obese }\end{array}$ & HOMA-IR & 1.880 .23 & & \\
\hline
\end{tabular}

>, greater than; BMI, Body Mass Index; BW, Body weight; Cer, Ceramides; F, female; HE, hyperinsulinemic euglycemic; HOMA-IR, Homeostatic Model Assessment of Insulin Resistance, IMTG, intramuscular trigycerides; IS, insulin sensitivity; M, male; min, minutes; $n$, number of subjects; OW, overweight; Sat, saturated; $\mathrm{VO}_{2}$ peak, peak oxygen uptake; $\mathrm{y}$, years; ${ }^{\wedge}$, $\mu$ mol glucose infused $\cdot \mathrm{kg} \mathrm{FFM}^{-1} \cdot \mathrm{min}$; Rel, relative * (milliliters per kilogram per minute ); $\ddagger$, (milliliters per kilogram of fat free mass per minute ). 


\section{Longitudinal Studies in Rodents}

Table 2. Exercise training studies in rodents.

\begin{tabular}{|c|c|c|c|c|c|c|c|c|c|c|c|c|c|}
\hline Reference & Subjects & Age & $\begin{array}{l}\text { Aerobic } \\
\text { Fitness }\end{array}$ & Health/BMI & $\begin{array}{c}\text { PA } \\
\text { Modification }\end{array}$ & $\begin{array}{l}\text { Ceramide } \\
\text { Method }\end{array}$ & $\begin{array}{c}\text { Muscle } \\
\text { Ceramide }\end{array}$ & $\begin{array}{l}\text { Ceramide } \\
\text { Species }\end{array}$ & IS Method & IS (PRE) & IS (Post) & Associations & Note \\
\hline \multirow[b]{2}{*}{$\begin{array}{c}\text { Dobrzyń } \\
\text { et al. (2004) } \\
{[56]}\end{array}$} & $\begin{array}{l}\text { Rat (Wistar) } \\
\quad(10 \mathrm{M})\end{array}$ & $\begin{array}{l}250-280 \\
\mathrm{~g}\end{array}$ & Sed & Lean & Control & & $\sim 135 \mathrm{nmol} / \mathrm{g}$ & - & - & - & - & - & - \\
\hline & $\begin{array}{l}\text { Rat (Wistar) } \\
\text { AET (10 M) }\end{array}$ & $\begin{array}{l}250-280 \\
\mathrm{~g}\end{array}$ & Sed & Lean & $\begin{array}{l}6 \mathrm{wk} \text { forced } \\
\text { treadmill } \\
\text { running }\end{array}$ & TLC, GLC & $\begin{array}{l}\sim 80 \mathrm{nmol} / \mathrm{g} \downarrow \text {, } \\
\text { sat in oxidative } \\
\text { muscles }\end{array}$ & $\begin{array}{c}\downarrow \mathrm{C} 14, \\
\text { C16, } \\
\text { C16:1, } \\
\text { C18, 20:4, } \\
22,24: 1\end{array}$ & - & - & - & - & $\begin{array}{c}\downarrow \text { SM, } \\
\uparrow \text { sphinganine } \\
\text { nSMase, } \\
\leftrightarrow \text { sphingosine }\end{array}$ \\
\hline \multirow[b]{2}{*}{$\begin{array}{l}\text { Tsalouhidou } \\
\text { et al. (2009) } \\
\text { [57] }\end{array}$} & $\begin{array}{l}\text { Rat (Wistar) } \\
\text { Sed (15 M) }\end{array}$ & $7 \mathrm{wk}$ & Sed & Lean & Control & \multirow{2}{*}{$\begin{array}{c}\text { one- } \\
\text { dimensional } \\
\text { TLC-GC }\end{array}$} & $\begin{array}{c}0.33 \pm 0.16 \\
\mu \mathrm{mol} / \mathrm{g}\end{array}$ & $\leftrightarrow$ & - & - & - & None & $\begin{array}{c}\text { PC, PE, PI, PS, } \\
\text { CL, SM and LPC } \\
\text { unchanged }\end{array}$ \\
\hline & $\begin{array}{l}\text { Rat (Wistar) } \\
\text { AET ( } 20 \mathrm{M})\end{array}$ & $7 \mathrm{wk}$ & $\begin{array}{c}\text { Sed, } \\
\text { Improved }\end{array}$ & Lean & $\begin{array}{l}8 \text { wk } \\
\text { voluntary } \\
\text { wheel } \\
\text { running }\end{array}$ & & $\begin{array}{c}\mathrm{BL}= \\
0.27 \pm 0.06 \\
\mu \mathrm{mol} / \mathrm{g}\end{array}$ & $\leftrightarrow$ & - & - & - & & $31 \% \downarrow$ PI \\
\hline \multirow[b]{2}{*}{$\begin{array}{c}\text { Błachnio- } \\
\text { Zabielska } \\
\text { et al. (2011) } \\
\text { [58] }\end{array}$} & $\begin{array}{l}\text { Rat (Wistar) } \\
\text { Sed (8 M) }\end{array}$ & $\begin{array}{l}200-250 \\
\mathrm{~g}\end{array}$ & Sed & Lean & Control & & $\begin{array}{c}24.57 \pm 3.53 \\
\mathrm{nmol} / \mathrm{g} \text { wet wt }\end{array}$ & - & HOMA-IR & - & $1.13 \pm 0.10$ & $\begin{array}{c}\text { Wrong } \\
\text { direction }\end{array}$ & - \\
\hline & $\begin{array}{l}\text { Rat (Wistar) } \\
\text { AET }(8 \mathrm{M})\end{array}$ & $24 \mathrm{~h}$ post & Sed & Lean & $\begin{array}{l}5 \mathrm{wk} \text { forced } \\
\text { treadmill } \\
\text { running }\end{array}$ & $\begin{array}{l}\text { HPLC } \\
\text { (C17 std) }\end{array}$ & $\begin{array}{c}28.70 \pm 3.59 \\
\mathrm{nmol} / \mathrm{g} \text { wet } \mathrm{wt}\end{array}$ & - & HOMA-IR & - & $0.54 \pm 0.04 \downarrow$ & $\begin{array}{l}\text { Wrong } \\
\text { direction }\end{array}$ & $\begin{array}{c}\text { Plasma FFA } \\
>100 \% \text { lower, } \\
\text { > Sphinganine, } \\
\text { SPA1P, SPT2 and } \\
\text { aSMase. } \\
\downarrow \text { nCDase and } \\
\text { alCDase }\end{array}$ \\
\hline \multirow{2}{*}{$\begin{array}{c}\text { Holloway } \\
\text { et al. (2014) } \\
\text { [59] }\end{array}$} & $\begin{array}{l}\text { Rat (Zucker) } \\
\quad(18 \mathrm{~F})\end{array}$ & $\sim 255 \mathrm{~g}$ & Sed & Lean & $\begin{array}{l}6 \mathrm{~d} \text { e-stim } \\
6 \mathrm{~h} / \mathrm{d}\end{array}$ & \multirow{2}{*}{ TLC, GLC } & $\begin{array}{l}\leftrightarrow \text { Red, } \downarrow \\
\text { White }\end{array}$ & $\begin{array}{l}\leftrightarrow \text { Red, } \downarrow \\
\text { White }\end{array}$ & \multirow{2}{*}{$\begin{array}{l}\text { 3-OMG in } \\
\text { perfused } \\
\text { hindlimb }\end{array}$} & $\begin{array}{l}\text { Lean }> \\
\text { Obese }\end{array}$ & $\begin{array}{l}\uparrow, \text { but Lean }> \\
\text { Obese }\end{array}$ & \multirow{2}{*}{$\begin{array}{l}\text { + TAG, lipid } \\
\text { droplet size } \\
\text { + TAG, lipid } \\
\text { droplet size }\end{array}$} & $\uparrow$ lipid droplets \\
\hline & $\begin{array}{l}\text { Rat (Zucker) } \\
\quad(18 \mathrm{~F})\end{array}$ & $\sim 350 \mathrm{~g}$ & Sed & Obese & $\begin{array}{c}6 \mathrm{~d} \text { e-stim } \\
6 \mathrm{~h} / \mathrm{d}\end{array}$ & & $\downarrow \downarrow$ & $\downarrow \downarrow \mathrm{C} 18$ & & - & $\uparrow$ & & $\uparrow \uparrow$ lipid droplets \\
\hline
\end{tabular}

$\uparrow$, increase; $\uparrow \uparrow$, large increase; $\downarrow$, decrease; $\downarrow \downarrow$, large decrease; $\leftrightarrow$, no change; 3-OMG, 3-O-methylglucose; AET, aerobic exercise training; alCDase, alkaline ceramidase; aSMase, acid sphingomyelinase; BMI, Body Mass Index; BL, baseline; CL, cardiolipin; d, days; e-stim, electrical stimulation; F, female; FFA, free fatty acids; $g$, grams; GC, gas chromatography; GLC, gas-liquid chromatography; h, hours; HOMA-IR, homeostatic model assessment of insulin resistance; HPLC, high-performance liquid chromatography; IS, insulin sensitivity; LPC, lysophosphatidyl choline; M, male; $n$, number of subjects; $\mathrm{nCDase}$, neutral ceramidase; nmol/g, nanomole per gram; nSMase, neutral sphingomyelinase; PC, phosphatidyl choline; PE, phosphatidyl ethanolamine; PI, phosphatidyl inositol; PS, Phosphatidyl serine; Red, red portion of gastrocnemius; sat, saturated; Sed, sedentary; SM, sphingomyelin; SPA1P, sphinganine-1-phosphate; SPT2, serine palmitoyltransferase 2; TAG, triglycerides; TLC, thin-layer chromatography; White, white portion of gastrocnemius; wk, weeks; wt, weight. 
The literature on exercise training and muscle ceramide content in rodent is varied (Table 2). The first longitudinal exercise training study (six-weeks forced treadmill running) by Dobrzyn et al. showed decreased ceramide content in the soleus and red and white gastrocnemius of male rats [60]. Similar, but less pronounced effects were observed with muscle sphingomyelin with slight differences between muscle groups. The same study reported that exercise increased muscle sphinganine and nSMase, but not sphingosine, and suggested that ceramide flux through de novo synthesis rather than the salvage pathway may have been altered with training [60]. In contrast, a study examining 8-weeks of voluntary wheel running in male rats, did not reveal any changes in gastrocnemius lipids (phosphatidyl choline, phosphatidyl ethanolamine, phosphatidyl inositol, phosphatidyl serine, cardiolipin, ceramides, sphingomyelin, and lysophosphatidyl choline) except for phosphatidyl inositol, which decreased [57]. The divergent results of this current study compared to Dobrzyn et al. [60] may have been due to the form of exercise (forced treadmill running vs. voluntary wheel running), limited duration of treatment or more likely that the rats from the Dobrzyn et al. study were larger and older.

A following study from Dr. Jan Gorski's group using a more robust form of endurance exercise in male rats (i.e., treadmill running) demonstrated increased insulin sensitivity (HOMA-IR) and sphinganine in the soleus and red gastrocnemius similar to the previous report [60] but no change in sphingosine or S1P, dihydroceramide or ceramide [58]. They also showed an increase in SPT2 and aSMase activity (in the soleus) but only an increase in sphinganine-1-phosphate content and nSMase activity isolated to the gastrocnemius. [58]. Interestingly, enzymes related to the degradation of ceramide to sphingosine, $\mathrm{nCD}$ ase and alCDase, were decreased, yet ceramide content was unaltered. The authors speculated that other pathways of ceramide turnover (ceramide kinase, sphingomyelin synthase or glucosylceramide synthase) could have offset changes in ceramide abundance with exercise training. However, Hollaway and colleagues used chronic electrical stimulation to the hindlimb muscles $(6 \mathrm{~h} / \mathrm{d}$ for $6 \mathrm{~d}$ ) in lean and obese female (Zucker) rats, which resulted in improved insulin-stimulated glucose transport to muscle and increased TAG content and composition [59]. These authors also demonstrated an increase in the size and number of lipid droplets in the subsarcolemal and intramyofibrillar regions with exercise training as reviewed elsewhere [61]. Ceramide content and composition (species-specific) only decreased in obese, but not the lean rats [59]. These data provide further credence to the concept that chronic muscle contraction reduces the level of lipid intermediates only in conditions of frank IR associated with dyslipidemia, such as obesity and diabetes. Increased contractile activity increases long chain fatty acids into muscle as they are the necessary substrate to fuel chronic activity [62]. This increased transport of lipids into muscle is similar to overfeeding, however chronic activity increases oxidation of lipids and prioritizes lipid storage to reduce accumulation of lipid intermediates [61]. In fact, palmitate and FFA transport is increased with contractile activity $[62,63]$ and decreased during denervation (inactivity), a phenomenon that correlates with the abundance of membrane bound fatty acid transport proteins [62]. Thus, chronic exercise may reduce lipid intermediates, such as ceramide, only if they are profoundly elevated due to dietary excess or genetic disposition. Also, this discussion bring up the point that slow-twitch myofibers contain greater amounts of ceramide [64] and rodents typically have more fast-twitch muscle than humans, a factor that may explain some of the complexity and variation in the field. 


\section{Cross-Sectional Studies in Humans}

Table 3. Cross-sectional studies and muscle ceramides in humans.

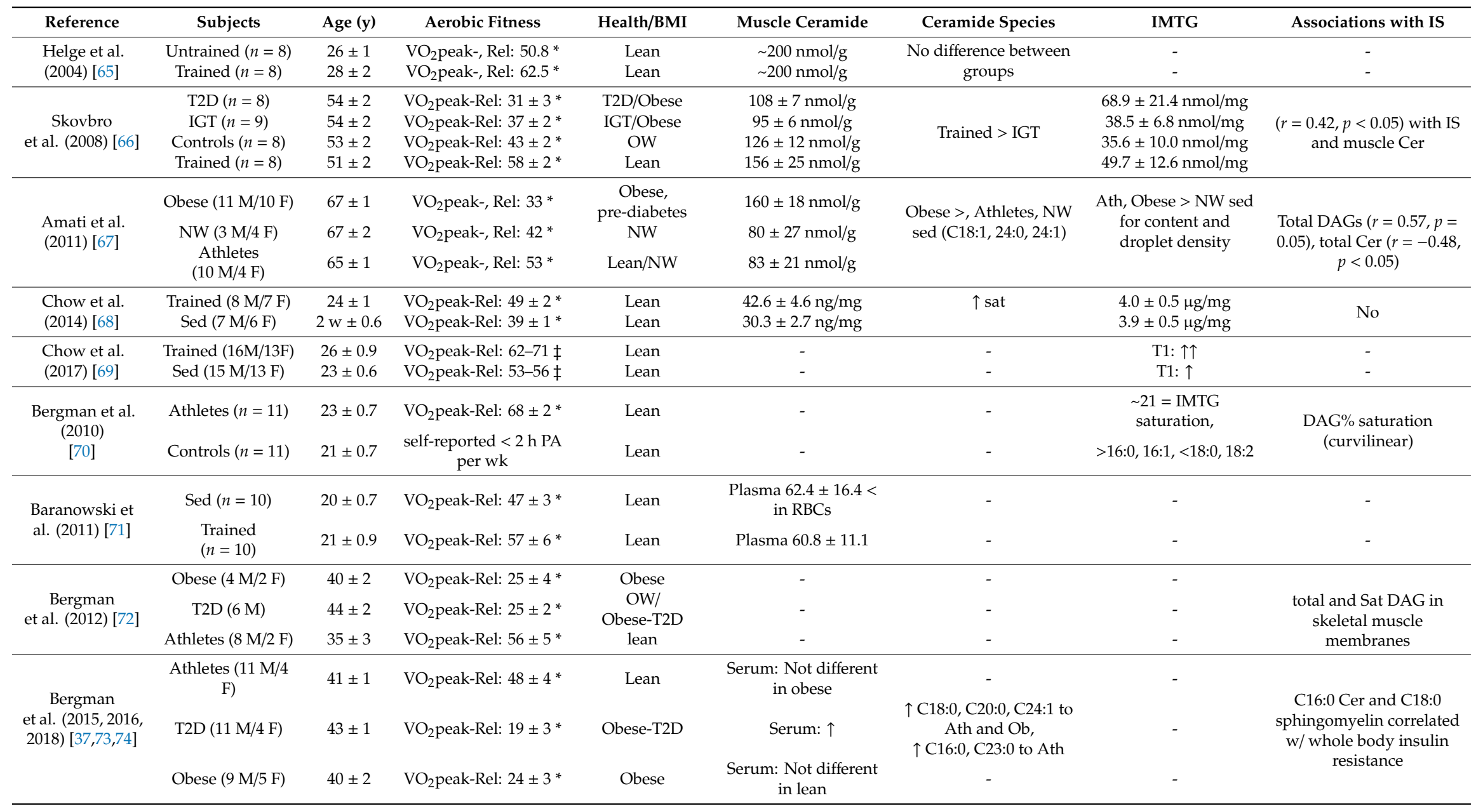


Table 3. Cont.

\begin{tabular}{|c|c|c|c|c|c|c|c|c|}
\hline Reference & Subjects & Age (y) & Aerobic Fitness & Health/BMI & Muscle Ceramide & Ceramide Species & IMTG & Associations with IS \\
\hline \multirow{2}{*}{$\begin{array}{l}\text { Bergman } \\
\text { et al. }(2016 \text {, } \\
\text { 2018) }[37,74]\end{array}$} & Athletes $(n=15)$ & $41 \pm 1$ & $\mathrm{VO}_{2}$ peak-Rel: $48 \pm 4^{*}$ & Lean & $\begin{array}{c}\text { C:24: }>\text { T2D and } \\
\text { Obese }\end{array}$ & - & - & \multirow{2}{*}{ Not total, but C:18 } \\
\hline & $\begin{array}{c}\text { T2D }(n=15) \\
\text { Obese }(n=14)\end{array}$ & $\begin{array}{l}43 \pm 1 \\
40 \pm 2\end{array}$ & $\begin{array}{l}\mathrm{VO}_{2} \text { peak-Rel: } 19 \pm 3^{*} \\
\mathrm{VO}_{2} \text { peak-Rel: } 24 \pm 3^{*}\end{array}$ & $\begin{array}{l}\text { Obese-T2D } \\
\text { Obese }\end{array}$ & C:18: > Ath = Obese & - & - & \\
\hline \multirow{4}{*}{$\begin{array}{l}\text { Søgaard } \\
\text { et al. (2019) } \\
\text { [28] }\end{array}$} & Young $(11 \mathrm{M})$ & $23 \pm 1$ & $\mathrm{VO}_{2}$ peak-Rel: $46 \pm 1^{*}$ & Lean & $622 \pm 74$ & > C:16, C:18,C:22 vs. & & \multirow{4}{*}{$\begin{array}{l}\text { In young: HOMA-IR } \\
\text { correlated with C16:0 and } \\
\text { total Cer. No association } \\
\text { in the old. }\end{array}$} \\
\hline & Young Trained & $23 \pm 1$ & $\mathrm{VO}_{2}$ peak-Rel: $53 \pm 2 *$ & Lean & $661 \pm 91$ & both OLD & - & \\
\hline & Old (18 M) & $66 \pm 1$ & $\mathrm{VO}_{2}$ peak-Rel: $31 \pm 1^{*}$ & Lean/OW & $410 \pm 66$ & - & - & \\
\hline & $\begin{array}{l}\text { Old Trained } \\
\quad(15 \mathrm{M})\end{array}$ & $64 \pm 1$ & $\mathrm{VO}_{2}$ peak-Rel: $43 \pm 4^{*}$ & Lean & $550 \pm 74$ & - & - & \\
\hline \multirow{4}{*}{$\begin{array}{l}\text { Perreault } \\
\text { et al. (2018) } \\
\text { [38] }\end{array}$} & Lean $(8 \mathrm{M} / 6 \mathrm{~F})$ & $43 \pm 2$ & Sed $(<2 \mathrm{~h} /$ wk PA $)$ & Lean & - & - & - & \multirow{4}{*}{$\begin{array}{l}\text { (-) Many sarcolemmal } \\
\text { lipids, Mito/ER, nuclear } \\
\text { C18; (+) mito ER/DAGs }\end{array}$} \\
\hline & $\begin{array}{l}\text { Athletes } \\
(10 \mathrm{M} / 6 \mathrm{~F})\end{array}$ & $43 \pm 1$ & Masters Athletes & Lean & - & - & - & \\
\hline & Obese (8 M/7 F) & $42 \pm 2$ & Sed $(<2 \mathrm{~h} /$ wk PA $)$ & Obese & - & - & - & \\
\hline & $\mathrm{T} 2 \mathrm{D}(7 \mathrm{M} / 5 \mathrm{~F})$ & $46 \pm 2$ & Sed $(<2 \mathrm{~h} / \mathrm{wk}$ PA $)$ & Obese-T2D & $\begin{array}{l}\text { > all, most in } \\
\text { sarcolemmal }\end{array}$ & $\begin{array}{c}>\mathrm{C} 16, \mathrm{C} 18 \\
\text { sarcolemmal, }>\mathrm{C} 18 \text { in } \\
\text { nuclear fraction }\end{array}$ & - & \\
\hline
\end{tabular}

$\uparrow$, increase; $\uparrow \uparrow$, large increase; Abs, absolute; Cer, ceramides; DAG, diacylglycerol; ER, endoplasmic reticulum; F, female: h, hour; HOMA-IR, homeostatic model assessment of insulin resistance; IGT, impaired glucose tolerance; IMTG, intramuscular trigycerides; IS, insulin sensitivity; M, male; Min, minutes; Mito, mitochondrial; $n$, number of subjects; ng/mg, nanogram per milligram; nmol/g, nanomole per gram; nmoL/mg, nanomole per milligram; NW, normal weight; OW, overweight; PA, physical Activity; RBCs, red blood Cells; Rel, relative; Sat, saturated; Sed, sedentary; T1, myosin heavy-chain 1; T2D, persons with type-2 diabetes mellitus; $\mathrm{VO}_{2}$ peak, peak oxygen uptake; $\mathrm{y}$, years; $\mu \mathrm{g} / \mathrm{mg}$, micrograms per milligram; Rel, relative * (milliliters per kilogram body weight per minute ); $\ddagger$ (milliliters per kilogram of fat free mass per minute). 
When examining cross-sectional studies of exercise-trained individuals compared to those that are sedentary, results when evaluating muscle ceramides are fairly ambiguous (Table 3 and Supplementary Table S1). The variation might be explained by body mass index (BMI) status rather than physical activity level, since ceramides are linked to IR in extremes of body mass [66]. Of note, cross-sectional studies between active and sedentary groups involve more than just physical activity level (e.g., genetic predisposition and daily nutritional intake), and that several of these studies are potentially underpowered [23] thus introducing a large source of variability. Nonetheless the use of age and BMI-matched sedentary controls with exercise-trained participants is a powerful design strategy to address the initial question of whether physical activity level and insulin sensitivity [75] are related to skeletal muscle ceramides. In one study, examination of healthy age- and BMI-matched exercise-trained and sedentary young adults found no difference in skeletal muscle ceramide content or species at rest, but less sphingomyelin was found in exercise-trained participants [65]. Another more recent study demonstrated that among relatively lean young and older participants there was no difference in skeletal muscle ceramide based on training status [28]. In contrast, another study showed greater basal total ceramide content and insulin sensitivity in trained vs. sedentary BMI-matched young subjects [68]. A possible explanation for these seemingly divergent findings could be that untrained participants in the former study were of similar aerobic fitness (see $\mathrm{VO}_{2}$ peak data in Table 3) to the trained subjects from the later study. Another consideration is that the greater ceramide content in the more trained subjects [68] may be indicative of active lipid delivery in trained individuals, and not necessarily a predisposition to cause IR. Further, a well-powered cross-sectional comparison of endurance-trained, sedentary and obese older adults demonstrated pronounced stepwise decreases in insulin sensitivity, yet only the obese group had elevated skeletal muscle ceramide content [67]. In that study, the difference in insulin sensitivity between the sedentary and endurance trained older adults was $\sim 20 \%$ and the two groups showed identical ceramide content and composition [67] suggesting a discordant relationship between insulin sensitivity and ceramides in the absence of obesity. This pattern was also shown in a cross-sectional comparison of exercise-trained and sedentary middle-aged adults with distinctly different insulin sensitivity levels [66]. A recent in-depth cross-sectional investigation by the laboratory of Dr. Brian Bergman compared middle-aged athletes, lean controls, obese controls, and T2DM patients to demonstrate similar stepwise and distinct group differences in insulin sensitivity and non-oxidative glucose disposal [38]. There were no differences in skeletal muscle total, mitochondrial/ER, nuclear, sarcolemmal, or cytosolic ceramide content and composition between age- and BMI-matched athletes vs. lean controls [38]. Sub-cellular ceramide localization of C18:0 and insulin sensitivity were correlated with pooled data from all the participants, however this relationship appeared to be driven by inclusion of the group of persons with T2DM [38] and independent of the physical activity level between athletes and lean controls. In summary, cross-sectional studies in young and old adult humans demonstrate that levels of insulin sensitivity due physical activity status are unlikely to be explained by skeletal muscle ceramide content or ceramide species. By comparison, these data indicate that muscle ceramides are likely to be elevated and related to insulin sensitivity during metabolic disturbances such as obesity and T2DM. 


\section{Longitudinal Studies in Humans}

Table 4. Exercise training studies in humans.

\begin{tabular}{|c|c|c|c|c|c|c|c|c|c|}
\hline Reference & Subjects & Age (y) & Aerobic Fitness & Health/BMI & Training & $\begin{array}{c}\text { Muscle } \\
\text { Ceramide }\end{array}$ & Ceramide Species & Muscle Fat or IMTG & Associations \\
\hline \multirow{2}{*}{$\begin{array}{l}\text { Bruce et al. (2004) } \\
\text { [76] }\end{array}$} & $\begin{array}{l}\text { Control } \\
(n=6)\end{array}$ & $46 \pm 3$ & \multirow{2}{*}{ Rel: $\sim 30 *$} & OW & \multirow{2}{*}{8 wk, AET } & - & - & $\mathrm{BL}<, \leftrightarrow \mathrm{IMTG}$ & \multirow{2}{*}{ No } \\
\hline & $\mathrm{T} 2 \mathrm{D}(n=7)$ & $48 \pm 2$ & & Obese & & - & - & $\mathrm{BL}>, \downarrow$ IMTG & \\
\hline $\begin{array}{c}\text { Bruce et al. (2006) } \\
\text { [77] }\end{array}$ & $\begin{array}{l}\text { Obese } \\
(4 \mathrm{M} / 5 \mathrm{~F})\end{array}$ & $36 \pm 3$ & Rel: $24 \pm 2 *$ & Obese & 8 wk, AET & BL $(734 \mathrm{nmol} / \mathrm{g}), \downarrow$ & $\begin{array}{l}\text { C16:0, C16:1, C18:0, } \\
\text { C18:1, C18:2, C20:0 }\end{array}$ & $\leftrightarrow$ & No \\
\hline $\begin{array}{l}\text { Dube et al. (2008) } \\
\text { [78] }\end{array}$ & $\begin{array}{c}\text { Old } \\
(9 \mathrm{M} / 16 \mathrm{~F})\end{array}$ & $66.4 \pm 0.8$ & $\begin{array}{c}\text { Rel: } 34 \pm 7 *, \uparrow \\
7 \%\end{array}$ & OW/Obese & $16 \mathrm{wk}, \mathrm{AET}$ & $\downarrow$ & - & $\uparrow \sim 21 \%$ & $\operatorname{Cer}\left(r^{2}=0.46, p=0.01\right)$ \\
\hline \multirow{2}{*}{$\begin{array}{c}\text { Dube et al. (2011) } \\
\text { [79] }\end{array}$} & $\begin{array}{c}\text { DIWL } \\
(3 \mathrm{M} / 5 \mathrm{~F})\end{array}$ & $67 \pm 2$ & Rel: $31 \pm 2 *, \leftrightarrow$ & $\begin{array}{l}\text { OW-Obese, } \\
\text { NGT-IGT }\end{array}$ & DIWL & $\mathrm{BL}=, \leftrightarrow$ & $\begin{array}{c}\downarrow \mathrm{C} 14: 0, \text { C20:0, C24:0; } \\
\uparrow \mathrm{C} 24: 1\end{array}$ & $\mathrm{BL}=, \downarrow$ IMTG & \multirow{2}{*}{$\begin{array}{l}\text { BL total and some cer } \\
\text { species, } \downarrow \text { in C16:0 and } \\
\text { C24:1 with improved IS }\end{array}$} \\
\hline & $\operatorname{Ex}(4 \mathrm{M} / 4 \mathrm{~F})$ & $68 \pm 2$ & Rel: $32 \pm 2 *, \leftrightarrow$ & $\begin{array}{l}\text { OW-Obese, } \\
\text { NGT-IGT }\end{array}$ & 16 wk; AET & $\begin{array}{l}\downarrow 30-40 \% \\
(>\text { DIWL) }\end{array}$ & $\begin{array}{c}\downarrow \text { all but C16:0, C18:1 } \\
\text { (>DIWL for C18:0, C24:1) }\end{array}$ & $\mathrm{BL}=, \uparrow \mathrm{IMTG}$ & \\
\hline \multirow{2}{*}{$\begin{array}{l}\text { Devrives et al. } \\
\text { (2013) [80] }\end{array}$} & Lean $(12 \mathrm{~F})$ & $41 \pm 2$ & Rel: $26 \pm 1 *, \uparrow$ & Lean & \multirow[t]{2}{*}{$12 \mathrm{wk}, \mathrm{AET}$} & $\underset{\leftrightarrow}{\sim 110 \mathrm{nmol} / \mathrm{g} \mathrm{dw}}$ & - & \multirow{2}{*}{$\begin{array}{l}\text { AET localizes IMCs } \\
\text { close to Mito and IMF, } \\
\text { away from SS }\end{array}$} & - \\
\hline & Obese (11 F) & $40 \pm 3$ & Rel: $19 \pm 2 *, \uparrow$ & Obese & & $\begin{array}{c}\sim 130 \mathrm{nmol} / \mathrm{g} \mathrm{dw} \\
\leftrightarrow\end{array}$ & - & & - \\
\hline \multirow{2}{*}{$\begin{array}{l}\text { Samjoo et al. } \\
\text { (2013) [81] }\end{array}$} & Lean $(9 \mathrm{M})$ & $38 \pm 3$ & Rel: $47 \pm 2 \ddagger, \uparrow$ & Lean & \multirow[t]{2}{*}{$12 \mathrm{wk}, \mathrm{AET}$} & $\leftrightarrow$ & - & \multirow{2}{*}{$\begin{array}{l}\text { AET localizes IMCs } \\
\text { close to Mito and IMF, } \\
\text { away from SS }\end{array}$} & \multirow{2}{*}{ No } \\
\hline & Obese (9 M) & $39 \pm 3$ & Rel:45 $\pm 2 \ddagger, \uparrow$ & Obese & & $\sim 100 \mathrm{nmol} / \mathrm{g}, \leftrightarrow$ & - & & \\
\hline \multirow{2}{*}{$\begin{array}{c}\text { Coen et al. (2015) } \\
\text { [82] }\end{array}$} & $\begin{array}{l}\text { Control } \\
(n=51)\end{array}$ & $42.1 \pm 9.9$ & \multirow[t]{2}{*}{ Rel: $\sim 18 \ddagger, \uparrow$} & OW/Obese & \multirow{2}{*}{$\begin{array}{c}\text { None, RYGB } \\
\text { post RYGB; } \\
12 \mathrm{wk}\end{array}$} & $\downarrow$ & $\downarrow 16,18: 1,24: 1$ & $\downarrow \downarrow$ & \multirow[t]{2}{*}{ No } \\
\hline & $\operatorname{Ex}(n=50)$ & $41.6 \pm 9.3$ & & OW/Obese & & $\downarrow \downarrow$ & $\downarrow 16,18,18: 1,24: 1$ & $\downarrow$ & \\
\hline \multirow{2}{*}{$\begin{array}{c}\text { Kasumov } \\
\text { et al. (2015) [83] }\end{array}$} & $\begin{array}{c}\mathrm{NGT} \\
(8 \mathrm{M} / 6 \mathrm{~F})\end{array}$ & $62 \pm 2$ & \multirow{2}{*}{$\begin{array}{l}\text { Absolute: } 2 \pm \\
0.1 \mathrm{~L} / \mathrm{min}\end{array}$} & Obese & \multirow[t]{2}{*}{$12 \mathrm{wk}$} & Plasma: $\mathrm{BL}=, \downarrow$ & $\downarrow \mathrm{C} 14: 0, \mathrm{C} 16: 0, \mathrm{C} 24: 0$ & - & \multirow[t]{2}{*}{$\begin{array}{c}\text { Total and C:14 cer } \\
\text { negative with GIR change }\end{array}$} \\
\hline & $\mathrm{T} 2 \mathrm{D}(5 \mathrm{M} / 5 \mathrm{~F})$ & $65 \pm 2$ & & T2D-Obese & & Plasma: $\mathrm{BL}=\downarrow$ & $\begin{array}{c}\downarrow \mathrm{C} 14: 0, \mathrm{C} 16: 0, \mathrm{C} 18: 1, \\
\mathrm{C} 24: 0\end{array}$ & - & \\
\hline
\end{tabular}


Table 4. Cont.

\begin{tabular}{|c|c|c|c|c|c|c|c|c|c|}
\hline Reference & Subjects & Age (y) & Aerobic Fitness & Health/BMI & Training & $\begin{array}{c}\text { Muscle } \\
\text { Ceramide }\end{array}$ & Ceramide Species & Muscle Fat or IMTG & Associations \\
\hline \multirow{2}{*}{$\begin{array}{c}\text { Søgaard } \\
\text { et al. (2016) [84] }\end{array}$} & $\begin{array}{c}\text { Control } \\
(10 \mathrm{M} / 6 \mathrm{~F})\end{array}$ & $31.3 \pm 1.5$ & Rel: $42 *$ & OW & 10 wk, AET & $\mathrm{BL}=$ & $\begin{array}{l}\text { No difference at BL, } \downarrow \\
\text { C22:0 }\end{array}$ & - & \multirow[t]{2}{*}{ No } \\
\hline & $\begin{array}{l}\text { Offspring } \\
\text { (12 M/7 F) }\end{array}$ & $33.1 \pm 1.4$ & Rel: $38 *$ & $\begin{array}{l}\text { OW-offspring } \\
\text { of T2D }\end{array}$ & $10 \mathrm{wk}, \mathrm{AET}$ & $\mathrm{BL}=$ & $\begin{array}{l}\text { No difference at BL, } \downarrow \\
\text { C22:0 }\end{array}$ & - & \\
\hline $\begin{array}{l}\text { McKenzie et al. } \\
\text { (2017) [85] }\end{array}$ & $\begin{array}{c}\text { HipFx } \\
(3 \mathrm{M} / 4 \mathrm{~F})\end{array}$ & $78.4 \pm 13.3$ & Low & OW & $\begin{array}{l}12 \text { wk RE } \\
\text { and RET }\end{array}$ & $\sim 100 \mathrm{nmol} / \mathrm{g}, \leftrightarrow$ & $\leftrightarrow$ & - & No \\
\hline \multirow{2}{*}{$\begin{array}{l}\text { Shepherd } \\
\text { et al. (2017) [86] }\end{array}$} & Obese $(8 \mathrm{M})$ & $24 \pm 2$ & \multirow{2}{*}{ Rel: $34 * \uparrow$} & Obese & $4 \mathrm{wk}$, HIIT & $\downarrow$ & $\downarrow$ Cer 18:0 & $\leftrightarrow$ & No \\
\hline & Obese $(8 \mathrm{M})$ & $26 \pm 2$ & & Obese & $4 \mathrm{wk}, \mathrm{AET}$ & $\downarrow$ & $\downarrow$ Cer 18:0 & $\leftrightarrow$ & No \\
\hline \multirow{2}{*}{$\begin{array}{l}\text { Søgaard } \\
\text { et al. } 2019 \text { [25] }\end{array}$} & $\begin{array}{l}\text { Young } \\
(5 \mathrm{M} / 9 \mathrm{~F})\end{array}$ & $32 \pm 2$ & \multirow{2}{*}{ Rel: $\sim 27^{*}$} & Obese & 6 wk, HIIT & $\leftrightarrow$ & $\leftrightarrow$ & $\leftrightarrow$ & \multirow{2}{*}{ Not reported } \\
\hline & $\begin{array}{c}\text { Old } \\
(11 \mathrm{M} / 11 \mathrm{~F})\end{array}$ & $63 \pm 1$ & & Obese & $6 \mathrm{wk}, \mathrm{HIIT}$ & $\downarrow$ & $\downarrow$ Cer Sat, 18:0 & $\leftrightarrow$ & \\
\hline
\end{tabular}

$>$, greater than; <, less than; $\uparrow$, increase; $\downarrow$, decrease; $\downarrow \downarrow$, large decrease; $\leftrightarrow$, no change; Abs, absolute; AET, aerobic exercise training; BL, baseline; BL=, no difference at baseline between groups; BMI, Body Mass Index; COX, cyclooxygenase; Cer, Ceramide; DIWL, diet-induced weight loss; Ex, exercise; dw, dry tissue weight; GIR, glucose infusion rate; HIIT, high intensity interval training; HipFx, hip fracture patients; IGT, impaired glucose tolerance; IMC, intramuscular ceramides; IMF, intramyofibrillar; IMTG, intramuscular triglycerides; IS, insulin sensitivity; M, men; Mito, mitochondrial; $n$, number of subjects; NGT, normal glucose tolerance; nmol/g, nanomole per gram; OW, overweight; Rel, relative; RET, resistance exercise training; RYGB, Roux-en-Y gastric bypass; SS, subsarcollemal; T2D, persons with type-2 diabetes mellitus; wk, week; Rel, relative * (milliliters per kilogram body weight per minute); $\ddagger$
( (milliliters per kilogram of fat free mass per minute). 
The improved insulin sensitivity following exercise training is well established [75]. Longitudinal exercise training studies (>8-weeks) increase insulin sensitivity $[76,77,86]$ and this occurs while decreasing IMTG content in T2DM [76] but not in otherwise healthy obese $[76,77,86]$ humans. Alternately, IMTG has been shown to increase with exercise training in obese older adults coupled with a decrease in muscle ceramide content $[78,79]$. This might suggest a partitioning of triacylglycerol (TAG) and IMTG to specific cellular locations after chronic exercise training [80,81]. In these studies, exercise training shifted IMTG storage away from the sarcolemmal fraction and in closer proximity to the mitochondrial and myofibrils-theoretically for more efficient access of fuel for use in contraction $[61,80,81]$. Interestingly, the storage of C18:0 ceramide in the sarcolemmal fraction of the cell is most associated with IR [38]. One could speculate that with physical inactivity the ectopic lipid storage in muscle may likely occur in the sarcolemmal regions of the cell where inhibition of insulin signaling is most likely to occur but this remains to be examined. Although no differences in cross-sectional studies between lean athletes and lean sedentary controls exist regarding the content, composition or localization of skeletal muscle ceramide [87] what remains unknown is if the cellular distribution of ceramide changes after a period of exercise training or physical inactivity to reflect the associated changes in insulin sensitivity.

Skeletal muscle ceramides decrease in obese $[77,78,82,83,86]$ and T2DM [83] humans following aerobic exercise training or aerobic interval training $[25,86]$ (Table 4 and Supplementary Table S2). However, exercise training studies in participants with a wide range of insulin sensitivities, including normal weight controls [84], normal weight offspring of T2DM [84] and lean men [81] and women [80] largely result in no changes in skeletal muscle ceramide content or specific ceramide species following similar aerobic exercise training. One recent study had young and old obese participants complete 6 weeks of aerobic interval training and demonstrated that only the older participants decreased select ceramide species [25], this was likely driven by a greater initial ceramide content in those older but obese participants. Eight of the ten training studies reported ceramide composition (i.e., specific moieties) and the two studies in lean subjects that reported no change of ceramides used a crude DAG kinase assay to assess ceramide content $[80,81]$. This latter assay does not distinguish ceramides from dihydroceramides nor does it resolve ceramides of differing chain lengths. Even though total ceramide was not changed in normal weight controls and offspring of T2DM, exercise training decreased C22:0, yet this was not associated with the improvement of insulin sensitivity [84]. A few other studies in obese subjects depicted a change in several other species after aerobic exercise training $[76,82]$ or interval training with ceramide C18:0 [86], however these changes were also not related to insulin sensitivity. A factor for consideration is that some $[77,81,85,86]$, but not all $[82,84]$ of these studies were underpowered. Alternatively, exercise training studies in obese older adults $[78,79]$ or obese adults with T2DM [83] display negative associations with total [78,79,83], C14:0 [83], and C-16:0 or C-24:1 [79] ceramide and insulin sensitivity. However, the mechanism (i.e., de novo, salvage, hydrolysis) for exercise training-induced changes in ceramides and enzymes of ceramide metabolism in human skeletal muscle is vastly unexplored. A need exists for a more comprehensive examination of skeletal muscle ceramide at the level of specific enzymes of ceramide metabolism and most importantly with the recently developed flux assays $[40,88,89]$. Interestingly, ceramide metabolism may influence other functions, such as exercise performance [90].

In summary, changes in ceramide content after exercise training may occur in individuals with obesity or T2DM, likely do not change in healthy individuals and these factors drive the impact of age. These improvements following exercise training in metabolically compromised individuals may occasionally be associated with the improved insulin sensitivity following exercise training. A major limitation appears to be the reliance on whole cell lysate ceramide content/composition, which may not be as precise as studies assessing subcellular localization or ceramide flux. 


\section{Mechanisms and Considerations}

\subsection{Are Ceramides Involved in the Development of IR or a Mechanism to Worsen the Severity of Inactivity-Induced IR in Aging?}

A panoply of studies with rodents clearly identifies a role for skeletal muscle ceramides in mediating insulin sensitivity under conditions with pronounced derangements in metabolic function $[23,87,91]$. Yet, even under extreme differences in metabolic function the association of skeletal muscle ceramide content with IR in humans is inconsistent [24,66,92] and not well correlated [93]. Ceramides are not linked to skeletal muscle IR in aging specifically, but only with extremes of body mass [66], severity of metabolic dysfunction linked to diet [94], or disease [21,37,92,95]. Collectively, these reports suggest that skeletal muscle ceramide content may not be involved in the development of IR from physical inactivity from aging, though they likely worsen the condition during aging-associated obesity and metabolic dysfunction.

\subsection{Subcellular Assessments of Ceramide}

If the effect of ceramide on IR in healthy humans is subtle then the assessment of ceramide content and composition needs to be specific to capture the relationship. More recent reports have revealed that skeletal muscle subsarcolemma C16:0 [40,89] and sarcolemmal or mitochondrial or nuclear C18:0 [38] ceramide are more tightly associated with insulin sensitivity. This is an important point since the majority of studies evaluated in this review article assess the total skeletal muscle homogenate while some measured the specific ceramide species and only two studies to date have examined the subcellular localization of muscle ceramide $[38,64]$. Whether physical inactivity-induced IR is modulated through a certain lipid intermediate species in a specific myocellular location remains sparsely examined [64]. Exercise training shifts intramuscular triglycerides from subsarcolemma to intramyofibrillar and mitochondrial locations $[61,80]$ to more efficiently store fuel for contraction [61]. Therefore, it would be intriguing to extensively test the hypothesis that during the time course of inactivity there is a gradual shift in lipotoxic ceramides to the subsarcolemal region where their presence is more likely to inhibit insulin signaling. Indeed, the localization of ceramide or diacylglycerol near the plasma membrane is a key determinate of the signaling actions to inhibit insulin action. Muscle cell culture models from divergent species demonstrate differences in the mechanism of ceramide to inhibit insulin signaling in culture [96] and in vivo [97]. Subcellular localization to the sarcolemmal region is likely a mechanism where ceramide can inhibit various portions of the insulin signaling cascade [98]. Saturated ceramides are more prone to alter membrane lipid rafts and are thus able to manipulate cellular function [99], such as protein and various receptor actions [100]. Ceramides, such as C18:0, are also known to have more direct actions to inhibit insulin signaling via protein phosphatase 2 (PP2A) [101]. In addition to plasma membrane localization to inhibit insulin signaling, accumulation of ceramide in other areas of the cell (mitochondrial, nuclear) may be involved [38] in the dysregulation of muscle metabolism. When considering muscle ceramides, one cannot exclude the effects of other non-muscle cell types residing in muscle that could contribute to the ceramide pool. Immune [102], and endothelial cells are potential sources of ceramide in skeletal muscle and as such it is difficult to differentiate the sources of ceramide found in skeletal muscle homogenate or even the subcellular locations.

\subsection{Conclusions}

Altogether, this review of the literature points to a dynamic response of skeletal muscle ceramide metabolism to physical activity, the significance of which is not fully understood. Aging itself does not appear to impact skeletal muscle ceramide content independent of physical inactivity, obesity and metabolic disruption that typically are associated with the aging process. Cross-sectional comparison participants by activity level and chronic exercise training does not support a relationship between skeletal muscle ceramide content and insulin sensitivity in healthy individuals. In agreement with this 
finding, chronic exercise training does not consistently reduce ceramide content linked to improved insulin sensitivity - a relationship that is occasionally observed in participants with robust metabolic dysfunction. Future considerations include more frequent assessments and longer durations of physical activity and inclusion of sex as a biological variable. Thus, the role of ceramide lipotoxicity in the early development of aging-induced IR is yet to be determined and resolution of this question would greatly benefit from the modern comprehensive lipidomic assessments of sphingolipids, in specific myocellular localizations and certainly with addition of ceramide flux assays. The possibility of subtle subcellular redistribution of skeletal muscle ceramide not detectable in whole muscle homogenate cannot yet be discounted in the etiology of age-induced skeletal muscle IR. If skeletal muscle ceramide intramyocelluar distribution and content is not involved in the development of age-induced IR, it is probable that ceramides may serve as a likely mechanism to worsen the progression of metabolic dysfunction into metabolic disease during longer durations of inactivity and during aging.

\subsection{Future Challenges and Directions}

Clearly, a divergence in the rodent [23,103] and human research [24] is present surrounding the effects of skeletal muscle ceramide on metabolism. These observations could suggest (1) intrinsic differences between rodents and humans surrounding overall metabolism and ceramide content/composition [65], (2) differences in the analytical methods to quantify ceramides [91], (3) imprecise and non-biologically specific assessment of lipid intermediates to capture modest differences (compared to rodent research) in insulin sensitivity and (4) the reality that we can only sample a small percentage of human muscle whereas the whole muscle or a larger portion is sampled from the rodent. Even with these limitations, there is a need to conduct mechanistic mouse studies of ceramide metabolism examining the interaction between aging, physical activity level and insulin sensitivity.

\section{Summary}

- Though lipid/obesity induced insulin resistance is well examined, the mechanism(s) linking activity to insulin sensitivity is largely unknown, particularly in aging.

- Aging is only linked to increased skeletal muscle ceramide content in obese individuals.

- Cross-sectional studies of exercise-trained adults reveal a range of insulin sensitivities related to physical activity level that are independent of skeletal muscle ceramide content and species. Indeed, acute exercise in healthy humans may actually increase ceramide content within skeletal muscle.

- By comparison, longitudinal studies indicate that exercise may not impact ceramides in skeletal muscle of healthy individuals but is rather more likely to decrease skeletal muscle ceramides in individuals with previously elevated ceramides resulting from obesity or T2D.

- Clarity of the role of skeletal muscle ceramides on insulin sensitivity during physical activity may be enhanced with improved methodologies to evaluate distinct ceramide species (e.g., with different acyl-chains), their subcellular distribution, and their turnover. Additionally, there is a need for mechanistic genetic studies of ceramide metabolism examining the interaction between physical activity level and insulin sensitivity. Greater attention to these nuances of ceramide action could unveil relationships which may be masked in prior literature.

Supplementary Materials: The following are available online at http://www.mdpi.com/1422-0067/21/4/1514/s1, Table S1: Methods of cross-sectional studies and muscle ceramides in humans, Table S2: Methods of exercise training studies in humans.

Author Contributions: All authors provided significant contribution to this review article. All authors have read and agreed to the published version of the manuscript.

Funding: This project was supported in part by a Jeane B. Kempner Award and National Institutes of Health awards F32 AR072481 (to P.T.R.), R01 AG050781 (to M.J.D.), and R01 DK115824 (to S.A.S.).

Conflicts of Interest: SAS is a cofounder, consultant, and shareholder for Centaurus Therapeutic. 


\section{References}

1. Agha, M.; Agha, R. The rising prevalence of obesity: Part A: Impact on public health. Int. J. Surg. $2017,2$. [CrossRef]

2. Vorup, J.; Pedersen, M.T.; Brahe, L.K.; Melcher, P.S.; Alstrøm, J.M.; Bangsbo, J. Effect of small-sided team sport training and protein intake on muscle mass, physical function and markers of health in older untrained adults: A randomized trial. PLoS ONE 2017, 12. [CrossRef]

3. Data \& Statistics. Diabetes; CDC: Atlanta, GA, USA, 2017.

4. Liao, C.-D.; Tsauo, J.-Y.; Wu, Y.-T.; Cheng, C.-P.; Chen, H.-C.; Huang, Y.-C.; Chen, H.-C.; Liou, T.-H. Effects of protein supplementation combined with resistance exercise on body composition and physical function in older adults: A systematic review and meta-analysis. Am. J. Clin. Nutr. 2017, 106, 1078-1091. [CrossRef]

5. Centers for Disease Control and Prevention. National Diabetes Statistics Report; U.S. Dept. of Health and Human Services: Atlanta, GA, USA, 2017.

6. WHO. Prevalence of Insufficient Physical Activity; World Health Organization: Geneva, Switzerland, 2015.

7. Thyfault, J.P.; Krogh-Madsen, R. Metabolic disruptions induced by reduced ambulatory activity in free-living humans. J. Appl. Physiol. 2011, 111, 1218-1224. [CrossRef]

8. Thyfault, J.P.; Booth, F.W. Lack of regular physical exercise or too much inactivity. Curr. Opin. Clin. Nutr. Metab. Care 2011, 14, 374-378. [CrossRef]

9. Mechling, H.; Netz, Y. Aging and inactivity-Capitalizing on the protective effect of planned physical activity in old age. Eur. Rev. Aging Phys. Act. 2009, 6, 89-97. [CrossRef]

10. Booth, F.W.; Zwetsloot, K.A. Basic concepts about genes, inactivity and aging. Scand. J. Med. Sci. Sports 2010, 20, 1-4. [CrossRef]

11. Kennedy, R.L.; Chokkalingham, K.; Srinivasan, R. Obesity in the elderly: Who should we be treating, and why, and how? Curr. Opin. Clin. Nutr. Metab. Care 2004, 7, 3-9. [CrossRef]

12. Watson, K.B.; Carlson, S.A.; Gunn, J.P.; Galuska, D.A.; O'Connor, A.; Greenlund, K.J.; Fulton, J.E. Physical Inactivity Among Adults Aged 50 Years and Older-United States, 2014. Morb. Mortal. Wkly. Rep. 2016, 65, 954-958. [CrossRef]

13. Booth, F.W.; Roberts, C.K.; Laye, M.J. Lack of exercise is a major cause of chronic diseases. Compr. Physiol. 2012, 2, 1143-1211.

14. Booth, F.W.; Roberts, C.K.; Thyfault, J.P.; Ruegsegger, G.N.; Toedebusch, R.G. Role of Inactivity in Chronic Diseases: Evolutionary Insight and Pathophysiological Mechanisms. Physiol. Rev. 2017, 97, 1351-1402. [CrossRef] [PubMed]

15. Fink, R.I.; Kolterman, O.G.; Griffin, J.; Olefsky, J.M. Mechanisms of Insulin Resistance in Aging. J. Clin. Investig. 1983, 71, 1523-1535. [CrossRef] [PubMed]

16. Burant, C.F.; Lemmon, S.K.; Treutelaar, M.K.; Buse, M.G. Insulin resistance of denervated rat muscle: A model for impaired receptor-function coupling. Am. J. Physiol. Metab. 1984, 247, E657-E666. [CrossRef] [PubMed]

17. Robinson, K.A.; Boggs, K.P.; Buse, M.G. Okadaic acid, insulin, and denervation effects on glucose and amino acid transport and glycogen synthesis in muscle. Am. J. Physiol. Metab. 1993, 265, E36-E43. [CrossRef] [PubMed]

18. Sowell, M.O.; Boggs, K.P.; Robinson, K.A.; Dutton, S.L.; Buse, M.G. Effects of insulin and phospholipase $\mathrm{C}$ in control and denervated rat skeletal muscle. Am. J. Physiol. Metab. 1991, 260, E247-E256. [CrossRef] [PubMed]

19. Chaurasia, B.; Summers, S.A. Ceramides-Lipotoxic Inducers of Metabolic Disorders: (Trends in Endocrinology and Metabolism 26, 538-550; 2015). Trends Endocrinol. Metab. 2018, 29, 66-67. [CrossRef]

20. Kahn, S.E.; Hull, R.L.; Utzschneider, K.M. Mechanisms linking obesity to insulin resistance and type 2 diabetes. Nature 2006, 444, 840-846. [CrossRef]

21. Goodpaster, B.H.; Wolf, D. Skeletal muscle lipid accumulation in obesity, insulin resistance, and type 2 diabetes. Pediatr. Diabetes 2004, 5, 219-226. [CrossRef]

22. Lee, Y.S.; Li, P.; Huh, J.Y.; Hwang, I.J.; Lu, M.; Kim, J.I.; Ham, M.; Talukdar, S.; Chen, A.; Lu, W.J.; et al. Inflammation Is Necessary for Long-Term but Not Short-Term High-Fat Diet-Induced Insulin Resistance. Diabetes 2011, 60, 2474-2483. [CrossRef] 
23. Summers, S.A.; Goodpaster, B.H. CrossTalk proposal: Intramyocellular ceramide accumulation does modulate insulin resistance. J. Physiol. 2016, 594, 3167-3170. [CrossRef]

24. Petersen, M.C.; Jurczak, M.J. CrossTalk opposing view: Intramyocellular ceramide accumulation does not modulate insulin resistance. J. Physiol. 2016, 594, 3171-3174. [CrossRef] [PubMed]

25. Søgaard, D.; Baranowski, M.; Larsen, S.; Lund, M.T.; Scheuer, C.M.; Abildskov, C.V.; Dideriksen, S.G.; Dela, F.; Helge, J.W. Muscle-Saturated Bioactive Lipids Are Increased with Aging and Influenced by High-Intensity Interval Training. Int. J. Mol. Sci. 2019, 20, 1240. [CrossRef] [PubMed]

26. Rivas, D.A.; Morris, E.P.; Haran, P.H.; Pasha, E.P.; Morais, M.d.; Dolnikowski, G.G.; Phillips, E.M.; Fielding, R.A. Increased ceramide content and NFkappaB signaling may contribute to the attenuation of anabolic signaling after resistance exercise in aged males. J. Appl. Physiol. 2012, 113, 1727-1736. [CrossRef] [PubMed]

27. Moro, C.; Galgani, J.E.; Luu, L.; Pasarica, M.; Mairal, A.; Bajpeyi, S.; Schmitz, G.; Langin, M.; Liebisch, G.; Smith, S.R. Influence of gender, obesity, and muscle lipase activity on intramyocellular lipids in sedentary individuals. J. Clin. Endocrinol. Metab. 2009, 94, 3440-3447. [CrossRef]

28. Søgaard, D.; Baranowski, M.; Dela, F.; Helge, J.W. The Influence of Age and Cardiorespiratory Fitness on Bioactive Lipids in Muscle. J. Gerontol. A Biol. Sci. Med. Sci. 2019, 74, 778-786. [CrossRef]

29. Chee, C.; Shannon, C.E.; Burns, A.; Selby, A.L.; Wilkinson, D.; Smith, K.; Greenhaff, P.L.; Stephens, F.B. Relative Contribution of Intramyocellular Lipid to Whole-Body Fat Oxidation Is Reduced With Age but Subsarcolemmal Lipid Accumulation and Insulin Resistance Are Only Associated With Overweight Individuals. Diabetes 2016, 65, 840-850. [CrossRef]

30. Holland, W.L.; Knotts, T.A.; Chávez, J.A.; Wang, L.-P.; Hoehn, K.L.; Summers, S.A. Lipid Mediators of Insulin Resistance. Nutr. Rev. 2007, 65, 39-46. [CrossRef]

31. Kirwan, J.P. Plasma ceramides target skeletal muscle in type 2 diabetes. Diabetes 2013, 62, 352-354. [CrossRef]

32. Cavalli, A.L.; Ligutti, J.A.; Gellings, N.M.; Castro, E.; Page, M.T.; Klepper, R.E.; Palade, P.T.; McNutt, W.T.; Sabbadini, R.A. The Role of TNF $\alpha$ and Sphingolipid Signaling in Cardiac Hypoxia: Evidence that Cardiomyocytes Release TNF $\alpha$ and Sphingosine. Basic Appl. Myol. 2002, 12, 167-175.

33. Baranowski, M.; Błachnio-Zabielska, A.U.; Charmas, M.; Helge, J.W.; Dela, F.; Książek, M.; Długołęcka, B.; Klusiewicz, A.; Chabowski, A.; Jan, G. Exercise increases sphingoid base-1-phosphate levels in human blood and skeletal muscle in a time- and intensity-dependent manner. Eur. J. Appl. Physiol. 2015, 115, 993-1003. [CrossRef]

34. Mullen, T.D.; Hannun, Y.A.; Obeid, L.M. Ceramide synthases at the centre of sphingolipid metabolism and biology. Biochem. J. 2012, 441, 789-802. [CrossRef] [PubMed]

35. Turpin, S.M.; Nicholls, H.T.; Willmes, D.M.; Mourier, A.; Brodesser, S.; Wunderlich, C.M.; Mauer, J.; Xu, E.; Hammerschmidt, P.; Brönneke, H.S.; et al. Obesity-Induced CerS6-Dependent C16:0 Ceramide Production Promotes Weight Gain and Glucose Intolerance. Cell Metab. 2014, 20, 678-686. [CrossRef] [PubMed]

36. Raichur, S.; Wang, S.T.; Chan, P.W.; Li, Y.; Ching, J.; Chaurasia, B.; Dogra, S.; Ohman, M.K.; Takeda, K.; Sugii, S.; et al. CerS2 Haploinsufficiency Inhibits $\beta$-Oxidation and Confers Susceptibility to Diet-Induced Steatohepatitis and Insulin Resistance. Cell Metab. 2014, 20, 687-695. [CrossRef] [PubMed]

37. Bergman, B.C.; Brozinick, J.T.; Strauss, A.; Bacon, S.; Kerege, A.; Bui, H.H.; Sanders, P.; Siddall, P.; Wei, T.; Thomas, M.K.; et al. Muscle sphingolipids during rest and exercise: A C18:0 signature for insulin resistance in humans. Diabetologia 2016, 59, 785-798. [CrossRef] [PubMed]

38. Perreault, L.; Newsom, S.A.; Strauss, A.; Kerege, A.; Kahn, D.E.; Harrison, K.A.; Snell-Bergeon, J.K.; Nemkov, T.; D'Alessandro, A.; Jackman, M.R.; et al. Intracellular localization of diacylglycerols and sphingolipids influences insulin sensitivity and mitochondrial function in human skeletal muscle. JCI Insight 2018, 3. [CrossRef]

39. Tonks, K.T.; Coster, A.C.; Christopher, M.J.; Chaudhuri, R.; Xu, A.; Gagnon-Bartsch, J.; Chisholm, D.J.; James, D.E.; Meikle, P.J.; Greenfield, J.R.; et al. Skeletal muscle and plasma lipidomic signatures of insulin resistance and overweight/obesity in humans. Obesity 2016, 24, 908-916. [CrossRef]

40. Chung, J.O.; Koutsari, C.; Blachnio-Zabielska, A.U.; Hames, K.C.; Jensen, M.D. Intramyocellular Ceramides: Subcellular Concentrations and Fractional De Novo Synthesis in Postabsorptive Humans. Diabetes 2017, 66, 2082-2091. [CrossRef] 
41. Turner, N.; Lim, X.Y.; Toop, H.D.; Osborne, B.; Brandon, A.E.; Taylor, E.N.; Fiveash, C.E.; Govindaraju, H.; Teo, J.D.; McEwen, H.P.; et al. A selective inhibitor of ceramide synthase 1 reveals a novel role in fat metabolism. Nat. Commun. 2018, 9, 3165. [CrossRef]

42. Bikman, B.T.; Summers, S.A. Ceramides as modulators of cellular and whole-body metabolism. J. Clin. Investig. 2011, 121, 4222-4230. [CrossRef]

43. Rutkowski, J.M.; Halberg, N.; Wang, Q.A.; Holland, W.L.; Xia, J.Y.; Scherer, P.E. Differential transendothelial transport of adiponectin complexes. Cardiovasc. Diabetol. 2014, 13, 47. [CrossRef]

44. Holland, W.L.; Miller, R.A.; Wang, Z.V.; Sun, K.; Barth, B.M.; Bui, H.H.; Davis, K.E.; Bikman, B.T.; Halerg, N.; Rutkowski, J.M.; et al. Receptor-mediated activation of ceramidase activity initiates the pleiotropic actions of adiponectin. Nat. Med. 2011, 17, 55-63. [CrossRef] [PubMed]

45. Vasiliauskaité-Brooks, I.; Sounier, R.; Rochaix, P.; Bellot, G.; Fortier, M.; Hoh, F.; De Colibus, L.; Bechara, C.; Saied, E.M.; Arenz, C.; et al. Structural insights into adiponectin receptors suggest ceramidase activity. Nature 2017, 544, 120-123. [CrossRef]

46. Sharma, A.X.; Holland, W.L. Adiponectin and its Hydrolase-Activated Receptors. J. Nat. Sci. 2017, 3, e396. [PubMed]

47. Bergouignan, A.; Schoeller, D.A.; Normand, S.; Gauquelin-Koch, G.; Laville, M.; Shriver, T.; Desage, M.; Le Maho, Y.; Ohshima, H.; Gharib, C.; et al. Effect of Physical Inactivity on the Oxidation of Saturated and Monounsaturated Dietary Fatty Acids: Results of a Randomized Trial. PLoS Clin. Trials 2006, 1. [CrossRef] [PubMed]

48. Bergouignan, A.; Trudel, G.; Simon, C.; Chopard, A.; Schoeller, D.A.; Votruba, S.B.; Desage, M.; Burdge, G.C.; Gauquelin-koch, G.; Norm, S.; et al. Physical Inactivity Differentially Alters Dietary Oleate and Palmitate Trafficking. Diabetes 2009, 58, 367-376. [CrossRef] [PubMed]

49. Holland, W.L.; Bikman, B.T.; Wang, L.-P.; Yuguang, G.; Sargent, K.M.; Bulchand, S.; Knotts, T.A.; Shui, G.; Clegg, D.J.; Wenk, M.R.; et al. Lipid-induced insulin resistance mediated by the proinflammatory receptor TLR4 requires saturated fatty acid-induced ceramide biosynthesis in mice. J. Clin. Investig. 2011, 121, 1858-1870. [CrossRef] [PubMed]

50. Shi, H.; Kokoeva, M.V.; Inouye, K.; Tzameli, I.; Yin, H.; Flier, J.S. TLR4 links innate immunity and fatty acid-induced insulin resistance. J. Clin. Investig. 2006, 116, 3015-3025. [CrossRef]

51. Strle, K.; Broussard, S.R.; McCusker, R.H.; Shen, W.-H.; Johnson, R.W.; Freund, G.G.; Dantzer, R.; Kelley, K.W. Proinflammatory Cytokine Impairment of Insulin-Like Growth Factor I-Induced Protein Synthesis in Skeletal Muscle Myoblasts Requires Ceramide. Endocrinology 2004, 145, 4592-4602. [CrossRef]

52. Hammad, S.M.; Pierce, J.S.; Soodavar, F.; Smith, K.J.; Al Gadban, M.M.; Rembiesa, B.; Klein, R.L.; Hannun, Y.A.; Bielawski, J.; Bielawska, A. Blood sphingolipidomics in healthy humans: Impact of sample collection methodology. J. Lipid Res. 2010, 51, 3074-3087. [CrossRef]

53. Ryan, A.S. Insulin resistance with aging: Effects of diet and exercise. Sports Med. 2000, 30, 327-346. [CrossRef]

54. Amati, F.; Dubé, J.J.; Coen, P.M.; Stefanovic-Racic, M.; Toledo, F.G.; Goodpaster, B.H. Physical Inactivity and Obesity Underlie the Insulin Resistance of Aging. Diabetes Care 2009, 32, 1547-1549. [CrossRef] [PubMed]

55. Lanza, I.R.; Short, D.K.; Short, K.R.; Raghavakaimal, S.; Basu, R.; Joyner, M.J.; McConnell, J.P.; Nair, K.S. Endurance Exercise as a Countermeasure for Aging. Diabetes 2008, 57, 2933-2942. [CrossRef] [PubMed]

56. Dobrzyn, A.; Knapp, M.; Gorski, J. Effect of acute exercise and training on metabolism of ceramide in the heart muscle of the rat. Acta Physiol. Scand. 2004, 181, 313-319. [CrossRef]

57. Tsalouhidou, S.; Petridou, A.; Mougios, V. Effect of chronic exercise on DNA fragmentation and on lipid profiles in rat skeletal muscle. Exp. Physiol. 2009, 94, 362-370. [CrossRef]

58. Błachnio-Zabielska, A.; Zabielski, P.; Baranowski, M.; Gorski, J. Aerobic Training in Rats Increases Skeletal Muscle Sphingomyelinase and Serine Palmitoyltransferase Activity, While Decreasing Ceramidase Activity. Lipids 2011, 46, 229-238. [CrossRef]

59. Holloway, G.P.; Han, X.X.; Jain, S.S.; Bonen, A.; Chabowski, A. Chronic muscle stimulation improves insulin sensitivity while increasing subcellular lipid droplets and reducing selected diacylglycerol and ceramide species in obese Zucker rats. Diabetologia 2014, 57, 832-840. [CrossRef]

60. Dobrzyn, A.; Zendzian-Piotrowska, M.; Gorski, J. Effect of endurance training on the sphingomyelin-signalling pathway activity in the skeletal muscles of the rat. J. Physiol. Pharmacol. 2004, 55, 305-313.

61. Zacharewicz, E.; Hesselink, M.K.C.; Schrauwen, P. Exercise counteracts lipotoxicity by improving lipid turnover and lipid droplet quality. J. Intern. Med. 2018, 284, 505-518. [CrossRef] 
62. Koonen, D.P.Y.; Benton, C.R.; Arumugam, Y.; Tandon, N.N.; Calles-Escandon, J.; Glatz, J.F.C.; Luiken, J.J.F.P.; Bonen, A. Different mechanisms can alter fatty acid transport when muscle contractile activity is chronically altered. Am. J. Physiol. Metab. 2004, 286, E1042-E1049. [CrossRef]

63. Gorski, J.; Bonen, A. Palmitate incorporation into lipids pools of contracting red and white muscles. Mol. Cell. Biochem. 1997, 166, 73-83. [CrossRef]

64. Reidy, P.T.; McKenzie, A.I.; Mahmassani, Z.; Morrow, V.R.; Yonemura, N.M.; Hopkins, P.N.; Marcus, R.L.; Rondina, M.T.; Lin, Y.K.; Drummond, M.J. Skeletal muscle ceramides and relationship with insulin sensitivity after 2 weeks of simulated sedentary behaviour and recovery in healthy older adults. J. Physiol. 2018, 596, 5217-5236. [CrossRef] [PubMed]

65. Helge, J.W.; Dobrzyn, A.; Saltin, B.; Gorski, J. Exercise and training effects on ceramide metabolism in human skeletal muscle. Exp. Physiol. 2004, 89, 119-127. [CrossRef] [PubMed]

66. Skovbro, M.; Baranowski, M.; Skov-Jensen, C.; Flint, A.; Dela, F.; Gorski, J.; Helge, J.W. Human skeletal muscle ceramide content is not a major factor in muscle insulin sensitivity. Diabetologia 2008, 51, 1253-1260. [CrossRef] [PubMed]

67. Amati, F.; Dubé, J.J.; Alvarez-Carnero, E.; Edreira, M.M.; Chomentowski, P.; Coen, P.M.; Switzer, G.E.; Bickel, P.E.; Stefanovic-Racic, M.; Toledo, F.G.S.; et al. Skeletal muscle triglycerides, diacylglycerols, and ceramides in insulin resistance: Another paradox in endurance-trained athletes? Diabetes 2011, 60, 2588-2597. [CrossRef] [PubMed]

68. Chow, L.S.; Mashek, U.G.; Austin, E.; Eberly, L.E.; Persson, X.-M.; Mashek, M.T.; Seaquist, E.R.; Jensen, M.D. Training status diverges muscle diacylglycerol accumulation during free fatty acid elevation. Am. J. Physiol. Metab. 2014, 307, E124-E131. [CrossRef] [PubMed]

69. Chow, L.S.; Mashek, D.G.; Wang, Q.; Shepherd, S.O.; Goodpaster, B.H.; Dube, J.J. Effect of acute physiological free fatty acid elevation in the context of hyperinsulinemia on fiber type-specific IMCL accumulation. J. Appl. Physiol. 2017, 123, 71-78. [CrossRef] [PubMed]

70. Bergman, B.C.; Perreault, L.; Hunerdosse, D.M.; Koehler, M.C.; Samek, A.M.; Eckel, R.H. Increased intramuscular lipid synthesis and low saturation relate to insulin sensitivity in endurance-trained athletes. J. Appl. Physiol. 2010, 108, 1134-1141. [CrossRef] [PubMed]

71. Baranowski, M.; Charmas, M.; Dlugolecka, B.; Gorski, J. Exercise increases plasma levels of sphingoid base-1 phosphates in humans. Acta Physiol. 2011, 203, 373-380. [CrossRef]

72. Bergman, B.C.; Hunerdosse, D.M.; Kerege, A.; Playdon, M.C.; Perreault, L. Localisation and composition of skeletal muscle diacylglycerol predicts insulin resistance in humans. Diabetologia 2012, 55, 1140-1150. [CrossRef]

73. Bergman, B.C.; Brozinick, J.T.; Strauss, A.; Bacon, S.; Kerege, A.; Bui, H.H.; Sanders, P.; Siddall, P.; Kuo, M.S.; Perreault, L. Serum sphingolipids: Relationships to insulin sensitivity and changes with exercise in humans. Am. J. Physiol. Endocrinol. Metab. 2015, 309, E398-E408. [CrossRef]

74. Bergman, B.C.; Perreault, L.; Strauss, A.; Bacon, S.; Kerege, A.; Harrison, K.; Brozinick, J.T.; Hunerdosse, D.M.; Playdon, M.C.; Holmes, W.; et al. Intramuscular triglyceride synthesis: Importance in muscle lipid partitioning in humans. Am. J. Physiol. Endocrinol. Metab. 2018, 314, E152-E164. [CrossRef] [PubMed]

75. Magkos, F.; Sidossis, L.S. Exercise and Insulin Sensitivity-Where Do We Stand? You'd Better Run! Eur. Endocrinol. 2008, 4, 22-25. [CrossRef]

76. Bruce, C.R.; Kriketos, A.D.; Cooney, G.J.; Hawley, J.A. Disassociation of muscle triglyceride content and insulin sensitivity after exercise training in patients with Type 2 diabetes. Diabetologia 2004, 47, $23-30$. [CrossRef] [PubMed]

77. Bruce, C.R.; Thrush, A.B.; Mertz, V.A.; Bézaire, V.; Chabowski, A.; Heigenhauser, G.J.F.; Dyck, D.J. Endurance training in obese humans improves glucose tolerance and mitochondrial fatty acid oxidation and alters muscle lipid content. Am. J. Physiol. Metab. 2006, 291, E99-E107. [CrossRef] [PubMed]

78. Dubé, J.J.; Amati, F.; Stefanovic-Racic, M.; Toledo, F.G.S.; Sauers, S.E.; Goodpaster, B.H. Exercise-induced alterations in intramyocellular lipids and insulin resistance: The athlete's paradox revisited. Am. J. Physiol. Metab. 2008, 294, E882-E888. [CrossRef] [PubMed]

79. Dubé, J.J.; Amati, F.; Toledo, F.G.S.; Stefanovic-Racic, M.; Rossi, A.; Coen, P.; Goodpaster, B.H. Effects of weight loss and exercise on insulin resistance, and intramyocellular triacylglycerol, diacylglycerol and ceramide. Diabetologia 2011, 54, 1147-1156. [CrossRef] 
80. Devries, M.C.; Samjoo, I.A.; Hamadeh, M.J.; McCready, C.; Raha, S.; Watt, M.J.; Steinberg, G.R.; Tarnopolsky, M.A. Endurance Training Modulates Intramyocellular Lipid Compartmentalization and Morphology in Skeletal Muscle of Lean and Obese Women. J. Clin. Endocrinol. Metab. 2013, 98, 4852-4862. [CrossRef]

81. Samjoo, I.A.; Safdar, A.; Hamadeh, M.J.; Glover, A.W.; Mocellin, N.J.; Santana, J.; Little, J.P.; Steinberg, G.R.; Raha, S.; Tarnopolsky, M.A. Markers of Skeletal Muscle Mitochondrial Function and Lipid Accumulation Are Moderately Associated with the Homeostasis Model Assessment Index of Insulin Resistance in Obese Men. PLoS ONE 2013, 8. [CrossRef]

82. Coen, P.M.; Menshikova, E.V.; Distéfano, G.; Zheng, D.; Tanner, C.J.; Standley, R.A.; Helbling, N.L.; Dubis, G.S.; Ritov, V.B.; Xie, H.; et al. Exercise and Weight Loss Improve Muscle Mitochondrial Respiration, Lipid Partitioning, and Insulin Sensitivity After Gastric Bypass Surgery. Diabetes 2015, 64, 3737-3750. [CrossRef]

83. Kasumov, T.; Solomon, T.P.; Hwang, C.; Huang, H.; Haus, J.M.; Zhang, R.; Kirwan, J.P. Improved insulin sensitivity after exercise training is linked to reduced plasma C14:0 ceramide in obesity and type 2 diabetes. Obesity 2015, 23, 1414-1421. [CrossRef]

84. Søgaard, D.; Østergård, T.; Blachnio-Zabielska, A.U.; Baranowski, M.; Vigelsø, A.H.; Andersen, J.L.; Dela, F.; Helge, J.W. Training Does Not Alter Muscle Ceramide and Diacylglycerol in Offsprings of Type 2 Diabetic Patients Despite Improved Insulin Sensitivity. J. Diabetes Res. 2016, 2016, 1-12. [CrossRef] [PubMed]

85. McKenzie, A.I.; Briggs, R.A.; Barrows, K.M.; Nelson, D.S.; Kwon, O.S.; Hopkins, P.N.; Higgins, T.F.; Marcus, R.L.; Drummond, M.J. A pilot study examining the impact of exercise training on skeletal muscle genes related to the TLR signaling pathway in older adults following hip fracture recovery. J. Appl. Physiol. 2017, 122, 68-75. [CrossRef] [PubMed]

86. Shepherd, O.S.; Cocks, M.; Meikle, P.J.; Mellett, N.A.; Ranasinghe, A.M.; Barker, T.A.; Wagenmakers, A.J.M.; Shaw, C.S. Lipid droplet remodelling and reduced muscle ceramides following sprint interval and moderate-intensity continuous exercise training in obese males. Int. J. Obes. 2017, 41, 1745-1754. [CrossRef] [PubMed]

87. Summers, S. Ceramides in insulin resistance and lipotoxicity. Prog. Lipid Res. 2006, 45, 42-72. [CrossRef] [PubMed]

88. Chen, Y.; Berejnaia, O.; Liu, J.; Wang, S.-P.; Daurio, N.A.; Yin, W.; Mayoral, R.; Petrov, A.; Kasumov, T.; Zhang, G.-F.; et al. Quantifying ceramide kinetics in vivo using stable isotope tracers and LC-MS/MS. Am. J. Physiol. Metab. 2018, 315, E416-E424. [CrossRef]

89. Chung, J.O.; Koutsari, C.; Blachnio-Zablieska, A.U.; Hames, K.C.; Jensen, M.D. Effects of meal ingestion on intramyocellular ceramide concentrations and fractional de novo synthesis in humans. Am. J. Physiol. Endocrinol. Metab. 2017. [CrossRef]

90. Lewis, L.S.; Huffman, K.M.; Smith, I.J.; Donahue, M.P.; Slentz, C.A.; Houmard, J.A.; Hubal, M.J.; Hoffman, E.P.; Hauser, E.R.; Siegler, I.C.; et al. Genetic Variation in Acid Ceramidase Predicts Non-completion of an Exercise Intervention. Front. Physiol. 2018, 9. [CrossRef]

91. Chavez, J.A.; Summers, S.A. A Ceramide-Centric View of Insulin Resistance. Cell Metab. 2012, 15, 585-594. [CrossRef]

92. Bosma, M.; Kersten, S.; Hesselink, M.K.; Schrauwen, P. Re-evaluating lipotoxic triggers in skeletal muscle: Relating intramyocellular lipid metabolism to insulin sensitivity. Prog. Lipid Res. 2012, 51, 36-49. [CrossRef]

93. Adams, J.M.; Pratipanawatr, T.; Berria, R.; Wang, E.; DeFronzo, R.A.; Sullards, M.C.; Mandarino, L.J. Ceramide content is increased in skeletal muscle from obese insulin-resistant humans. Diabetes 2004, 53, 25-31. [CrossRef]

94. Covington, J.D.; Johannsen, D.L.; Coen, P.M.; Burk, D.H.; Obanda, D.N.; Ebenezer, P.J.; Tam, C.S.; Goodpaster, B.H.; Ravussin, E.; Bajpeyi, S. Intramyocellular Lipid Droplet Size Rather Than Total Lipid Content is Related to Insulin Sensitivity After 8 Weeks of Overfeeding. Obesity 2017, 25, 2079-2087. [CrossRef] [PubMed]

95. Straczkowski, M.; Kowalska, I.; Baranowski, M.; Nikołajuk, A.; Otziomek, E.; Zabielski, P.; Adamska, A.; Blachnio, A.; Górski, J.; Górska, M. Increased skeletal muscle ceramide level in men at risk of developing type 2 diabetes. Diabetologia 2007, 50, 2366-2373. [CrossRef] [PubMed]

96. Mahfouz, R.; Khoury, R.; Blachnio-Zabielska, A.; Turban, S.; Loiseau, N.; Lipina, C.; Stretton, C.; Bourron, O.; Ferre, P.; Foufelle, F.; et al. Characterising the Inhibitory Actions of Ceramide upon Insulin Signaling in Different Skeletal Muscle Cell Models: A Mechanistic Insight. PLoS ONE 2014, 9. [CrossRef] [PubMed] 
97. Boon, J.; Hoy, A.J.; Stark, R.; Brown, R.D.; Meex, R.C.; Henstridge, D.C.; Schenk, S.; Meikle, P.J.; Horowitz, J.F.; Kingwell, B.A.; et al. Ceramides Contained in LDL Are Elevated in Type 2 Diabetes and Promote Inflammation and Skeletal Muscle Insulin Resistance. Diabetes 2013, 62, 401-410. [CrossRef]

98. Galadari, S.; Rahman, A.; Pallichankandy, S.; Galadari, A.; Thayyullathil, F. Role of ceramide in diabetes mellitus: Evidence and mechanisms. Lipids Health Dis. 2013, 12. [CrossRef]

99. Pinto, S.N.; Silva, L.C.; Futerman, A.H.; Prieto, M. Effect of ceramide structure on membrane biophysical properties: The role of acyl chain length and unsaturation. Biochim. Biophys. Acta-Biomembr. 2011, 1808, 2753-2760. [CrossRef]

100. Storlien, L.H.; Jenkins, A.B.; Chisholm, D.J.; Pascoe, W.S.; Khouri, S.; Kraegen, E.W. Influence of dietary fat composition on development of insulin resistance in rats. Relationship to muscle triglyceride and omega-3 fatty acids in muscle phospholipid. Diabetes 1991, 40, 280-289. [CrossRef]

101. Mukhopadhyay, A.; Saddoughi, S.A.; Song, P.; Sultan, I.; Ponnusamy, S.; Senkal, C.E.; Snook, C.F.; Arnold, H.K.; Sears, R.C.; Hannun, Y.A.; et al. Direct interaction between the inhibitor 2 and ceramide via sphingolipid-protein binding is involved in the regulation of protein phosphatase $2 \mathrm{~A}$ activity and signaling. FASEB J. 2009, 23, 751-763. [CrossRef]

102. Camell, C.D.; Nguyen, K.Y.; Jurczak, M.J.; Christian, B.E.; Shulman, G.I.; Shadel, G.S.; Dixit, V.D. Macrophage-specific de Novo Synthesis of Ceramide Is Dispensable for Inflammasome-driven Inflammation and Insulin Resistance in Obesity. J. Biol. Chem. 2015, 290, 29402-29413. [CrossRef]

103. Chaurasia, B.; Summers, S.A. Ceramides-Lipotoxic Inducers of Metabolic Disorders. Trends Endocrinol. Metab. 2015, 26, 538-550. [CrossRef]

(C) 2020 by the authors. Licensee MDPI, Basel, Switzerland. This article is an open access article distributed under the terms and conditions of the Creative Commons Attribution (CC BY) license (http://creativecommons.org/licenses/by/4.0/). 